\title{
Investigation of the Influence of High Risk Human Papillomavirus on the Biochemical Composition of Cervical Cancer Cells Using Vibrational Spectroscopy
}

\author{
Kamila Ostrowska \\ Technological University Dublin \\ Alison Malkin \\ Technological University Dublin, alison.malkin@tudublin.ie \\ Aidan Meade \\ Technological University Dublin, aidan.meade@tudublin.ie \\ Follow this and additional works at: https://arrow.tudublin.ie/radart \\ Part of the Atomic Molecular and Optical Physics Commons \\ See next page for additional authors
}

\section{Recommended Citation \\ Ostrowska,K. et al (2010) Investigation of the Influence of High Risk Human Papillomavirus on the Biochemical Composition of Cervical Cancer Cells Using Vibrational Spectroscopy. Analyst, Vol 135, pp.3087-3093. doi:10.1039/COAN00571A}

This Article is brought to you for free and open access by the Radiation and Environmental Science Centre at ARROW@TU Dublin. It has been accepted for inclusion in Articles by an authorized administrator of ARROW@TU Dublin. For more information, please contact arrow.admin@tudublin.ie, aisling.coyne@tudublin.ie, gerard.connolly@tudublin.ie.

Funder: the Department of Education and Science Technological Sector Research Strand III programme and enabled through the National Biophotonics and Imaging Platform, Ireland, and the Integrated NanoScience Platform for Ireland, both funded by the Irish Government's Programme for Research in Third Level Institutions, Cycle 4, National Development Plan 2007-2013.

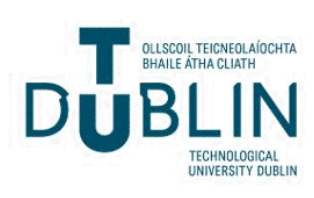




\section{Authors}

Kamila Ostrowska, Alison Malkin, Aidan Meade, John O'Leary, Cara Martin, Cathy Spillane, Hugh Byrne, and Fiona Lyng 


\title{
Investigation of the influence of high risk human papillomavirus on the biochemical composition of cervical cancer cells using vibrational spectroscopy
}

\author{
Kamila Magdalena Ostrowska, ${ }^{a}{ }^{a}$ Alison Malkin, ${ }^{b}$ Aidan Meade, ${ }^{c}$ John O’Leary, ${ }^{d}$ Cara Martin, ${ }^{d}$ \\ Cathy Spillane, ${ }^{d}$ Hugh James Byrne ${ }^{c}$ and Fiona Maria Lyng ${ }^{a}$
}

\author{
Received (in XXX, XXX) Xth XXXXXXXXX 200X, Accepted Xth XXXXXXXXX 200X \\ First published on the web $X$ th $X X X X X X X X X 200 X$ \\ DOI: $10.1039 / b 000000 x$
}

The main aetiology of cervical cancer is infection with high risk human papillomavirus (HPV).

${ }_{10}$ Cervical cancer is almost $100 \%$ curable if detected in the early stages. Thus, information about the presence and levels of HPV in patient samples has high clinical value. As current screening methods, such as the Pap smear test, are highly subjective and in many cases show low sensitivity and specificity, new supportive techniques are desirable to improve the quality of cervical cancer screening. In this study, vibrational spectroscopic techniques (Raman and Fourier Transform Infra ${ }_{15}$ Red absorption) have been applied to the investigation of four cervical cancer cell lines, HPV negative C33A, HPV-18 positive HeLa with 20-50 integrated HPV copies per cell, HPV-16 positive SiHa with 1-2 integrated HPV strands per cell and HPV-16 positive CaSki containing 60600 integrated HPV copies per cell. Results show that vibrational spectroscopic techniques can discriminate between the cell lines and elucidate cellular differences originating from proteins,

20 nucleic acids and lipids. Similarities between C33A and SiHa cells were exhibited in the Raman and infrared spectra and were confirmed by Principal Component Analysis (PCA). Analysis of the biochemical composition of the investigated cells, with the aid of PCA showed a clear discrimination between the C33A-SiHa group and HeLa and CaSki cell lines indicating the potential of vibrational spectroscopic techniques as support to current methods for cervical cancer 25 screening.

\section{Introduction}

Cervical cancer is second only to breast cancer as the most common malignancy in women worldwide ${ }^{1}$. The gradual progression of cervical cancer allows the application of 30 screening and diagnostic programmes to detect neoplastic changes before invasive cancer develops. The Papanicolaou test (also called the Pap test, Pap smear, or smear test) is a screening method which allows detection of infections and abnormalities of the cervix. The Pap smear test is the most 35 widespread screening method for cervical neoplasia ${ }^{2}$ and is based on visual evaluation of the morphology of cells collected from the cervix under light microscopy. Microscopic examination brings subjectivity to the screening results, therefore, the smear test has a hugely variable sensitivity $40(17 \%-99 \%)$ and specificity $(9 \%-100 \%)^{3}$.

The probability of developing cervical dysplasia is much higher for women infected with human papillomavirus (HPV) than those free of infection ${ }^{4}$. Infection with oncogenic or high- risk HPV (HPV-16, HPV-18) is the main risk factor for ${ }_{45}$ cervical cancer ${ }^{5}$ with $99.7 \%$ of invasive cervical neoplasia associated with HPV infection ${ }^{6}$. Thus, HPV testing has been added to the range of clinical options for cervical cancer screening. Detection of HPV (HPV testing) is based on detecting the DNA of the virus. It has been found that the ${ }_{50}$ DNA of high risk strains of HPV are assimilated within the cellular DNA of the host ${ }^{7}$. A drawback to HPV testing is that it is more expensive and time-consuming than other screening tests, and it requires a sophisticated laboratory infrastructure. Identifying the presence of HPV is a very important factor in 55 the prevention of cervical cancer. Technologies such as fluorescence or vibrational spectroscopies are being investigated as potential high sensitivity and specificity methodologies for cancer screening and diagnosis ${ }^{8-13}$.

Vibrational spectroscopy is a molecular specific spectroscopy 60 in which normal vibrational modes specific to molecular bonds as well as more complex molecular fingerprints are probed. There are two main vibrational spectroscopy techniques, Raman spectroscopy and infrared spectroscopy (IR), which give complementary spectral information. ${ }_{65}$ Vibrational spectroscopy is a powerful method delivering information about the chemical composition of a sample. Biomedical applications of vibrational spectroscopy are rapidly developing and it has been utilised in many studies to the detection of different types of cancer ${ }^{14-20}$. In the literature, 70 there is a wide spectrum of experiments concerning cervical cancer investigation with vibrational spectroscopy techniques, demonstrating the usefulness of these methods in understanding cervical cancer progression from the molecular level, and showing its potential application in cervical cancer 75 screening and diagnosis ${ }^{21-43}$. Raman spectroscopy has also been used to study cell lines derived from the cervix, revealing spectral variations, mostly in peaks originating from 


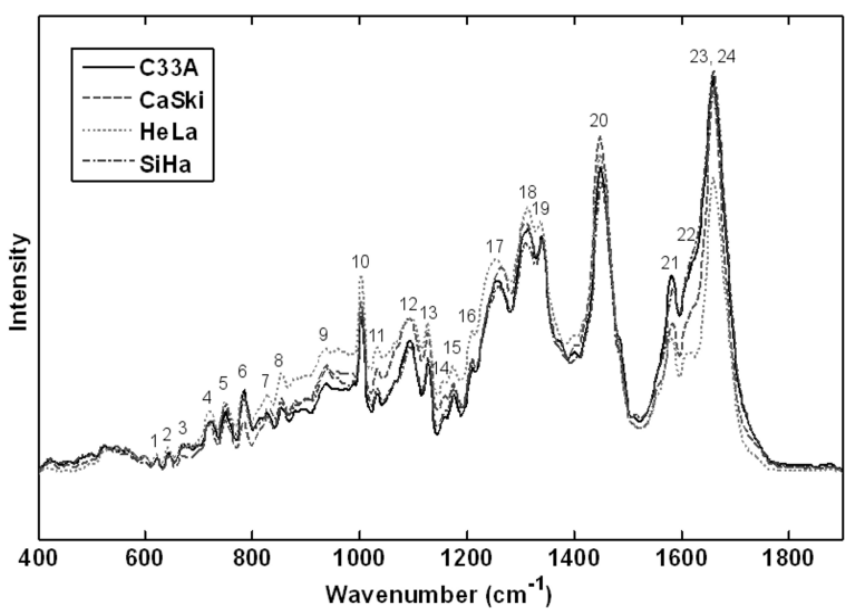

Fig. 1 Mean Raman spectra of cervical cancer cell lines.

DNA and proteins, in cell lines expressing the E7 gene of HPV-16 compared to cells not affected by HPV ${ }^{44}$. 5 Furthermore, a recent study has demonstrated that in lowgrade cytology infected with high-risk oncogenic HPV16 or HPV18, it was possible to differentiate samples from women based on whether they were aged 20-29 years vs. 30-39 years using attenuated total reflection infrared spectroscopy ${ }^{45}$.

10 In our study, four cervical cancer cell lines were investigated; HPV negative C33A, HPV-18 positive HeLa with 20-50 integrated HPV copies per cell, HPV-16 positive SiHa with 12 integrated HPV strands per cell and HPV-16 positive CaSki containing 60-600 integrated HPV copies per cell. The main 15 aim of the experiment was to investigate biochemical changes in cells caused by high risk HPV strands (HPV-16 and HPV18 ) and to examine whether it is possible to differentiate between the cells with no HPV copies and cells infected by low number, medium number and high number of integrated ${ }_{20}$ HPV copies, using vibrational spectroscopic techniques. Both common forms of vibrational spectroscopy, Raman and Fourier Transform Infrared absorption, were used to gain complementary information.

\section{Materials and Methods}

\section{${ }_{25}$ Cell culturing}

Cell lines were obtained from the ATCC cell culture collections. All cell lines were grown in RPMI 1640 medium (Sigma-Aldrich, Ireland) supplemented with 10\% Foetal Bovine Serum (FBS, BioWhittaker ${ }^{\circledR}$, Lonza, Ireland), $1 \%$ ${ }_{30}$ Penicillin-Streptomycin (BioWhittaker ${ }^{\circledR}$, Lonza, Ireland), 1\% L-glutamine (Sigma-Aldrich, Ireland), and $0.2 \%$ Hydrocortisone (Sigma-Aldrich, Ireland). Cells were incubated at $37^{\circ} \mathrm{C}$ in $5 \% \mathrm{CO} 2$ and maintained up to $70-80 \%$ confluency.

\section{${ }_{35}$ Sample preparation}

For Raman measurements, cervical cells were detached from the flasks using Trypsin - EDTA concentration (SigmaAldrich, Ireland) and centrifuged at $1200 \mathrm{rpm}$ for 5 minutes. After removing the supernatant, cells were washed twice in

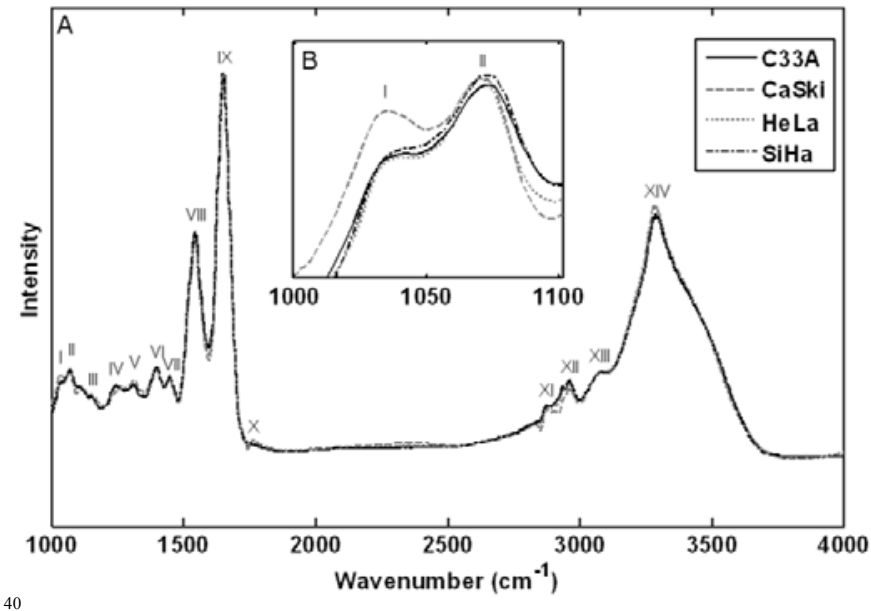

Fig. 2 (A) - Mean FTIR spectra of cervical cancer cell lines. (B) - FTIR spectra of cervical cancer cell lines in the range of 1000 to $1100 \mathrm{~cm}-1$.

Peak I, assigned to a $(\mathrm{C}-\mathrm{C})$ protein vibration, exhibits differences in intensity for CaSki cells, while peak II at $1072 \mathrm{~cm}-1$ assigned to

45 DNA/RNA shows a different intensity for the C33A cell line and a slight shift for C33A and SiHa in comparison to HeLa and CaSki.

PBS and centrifuged at 1200rpm for 6 minutes after each wash. Finally, the supernatant was removed and cellular pellets were transferred onto glass slides. The number of cells 50 transferred to one slide was in the range of $2-3 \times 10^{7}$ cells, yielding a pellet of dimensions $\sim 8 \times 8 \times 4 \mathrm{~mm}$. Cells for FTIR study were grown for 24 hours on $\mathrm{CaF}_{2}$ windows. Cells prepared for Raman and FTIR measurements were not fixed to avoid distortion of the cellular spectra ${ }^{46}$. Before FTIR 55 measurements, cells were washed twice in PBS and dried at $50^{\circ} \mathrm{C}$ to minimise contributions from water. Although cellular proteins can undergo denaturation at such temperatures, all cell lines were treated in exactly the same manner, allowing comparison of the spectroscopic features of the cell lines 60 investigated. Raman signals were accumulated from an undried pellet and in both cases the time between removal from the incubator to spectral measurement was minimised to 20-25mins.

\section{Raman measurements}

${ }_{65}$ Raman studies were performed using a Horiba J-Y Labram HR800 system operating with the 532nm Argon ion laser line. The laser power at the sample was measured and found to be $37.00 \pm 0.05 \mathrm{~mW}$. The backscattered light was collected by the objective lens and dispersed onto an air cooled CCD detector $70(1024 \times 256$ pixels $)$ by the grating. The dispersion of the system for the 600 lines $/ \mathrm{mm}$ grating was $\sim 2 \mathrm{~cm}^{-1} /$ pixel. A $\times 50$ objective lens was used for the measurements giving a spot size of $\sim 1 \mu \mathrm{m}$. Raman signals from two cellular pellets representing two cell culture passages were integrated for 60 75 seconds and measured over a spectral range of 400 to $1900 \mathrm{~cm}^{-}$ 1 . Random target areas within the pellets were chosen during the measurements. The thickness of the cellular pellets $(\sim 4 \mathrm{~mm})$ was high enough to avoid contribution from the glass slide in the collected biological spectra. However, this was 80 only possible during the first $30-40$ minutes of the measurements while the cellular material was not dried and 
Table 1 Peak assignments ${ }^{47}$ for Raman spectra data recorded for cervical cancer cell lines.

\begin{tabular}{|c|c|c|}
\hline Peak reference (figure 1) & Wavenumber $\left(\mathrm{cm}^{-1}\right)$ & Raman peak assignments \\
\hline 1 & 621 & $\mathrm{C}-\mathrm{C}$ twisting mode of Phe (proteins) \\
\hline 2 & 642 & C-C twisting mode of Tyr and Phe \\
\hline 3 & 670 & $\mathrm{C}, \mathrm{T}, \mathrm{G}$ (DNA/RNA) \\
\hline 4 & 720 & $\mathrm{C}-\mathrm{N}$ stretching in $\mathrm{A}$ and lipids \\
\hline 5 & 750 & symmetric breathing of Trp (protein) \\
\hline 6 & 782 & $\mathrm{U}, \mathrm{T}, \mathrm{C}$ (ring breathing modes in the DNA/RNA) \\
\hline 7 & 827 & $\mathrm{PO}_{2}$ stretching in DNA, Tyr \\
\hline 8 & 854 & Ring breathing in Tyr and Pro (proteins) \\
\hline 9 & 935 & $\mathrm{C}-\mathrm{C}$ stretching mode of Pro and Val \\
\hline 10 & 1003 & $\mathrm{C}-\mathrm{C}$ aromatic ring stretching in Phe \\
\hline 11 & 1031 & $\mathrm{C}-\mathrm{H}$ bending mode in Phenylalanine, $\mathrm{C}-\mathrm{N}$ stretching in proteins \\
\hline 12 & 1093 & symmetric $\mathrm{PO}_{2}$ stretching of the DNA backbone; lipids \\
\hline 13 & 1128 & $\mathrm{C}-\mathrm{N}$ stretching in proteins; C-O stretching in carbohydrates \\
\hline 14 & 1155 & $\mathrm{C}-\mathrm{C}$ and $\mathrm{C}-\mathrm{N}$ stretching of proteins \\
\hline 15 & 1175 & $\mathrm{C}-\mathrm{H}$ in plane bending mode of Tyr and Phe; $\mathrm{C}, \mathrm{G}$ \\
\hline 16 & 1208 & C- $\mathrm{C}_{6} \mathrm{H}_{5}$ stretching mode in Trp, Phe; \\
\hline 17 & $1220-1280$ & Amide III; A,C,T ring breathing modes of the DNA/RNA \\
\hline 18 & 1311 & $\mathrm{CH}_{3} / \mathrm{CH}_{2}$ twisting mode of collagen and lipid \\
\hline 19 & 1340 & $\mathrm{G}$ (DNA/RNA), $\mathrm{CH}$ deformation in proteins and carbohydrates; Trp \\
\hline 20 & 1450 & $\mathrm{CH}\left(\mathrm{CH}_{2}\right)$ bending mode in proteins and lipids \\
\hline 21 & 1583 & A,G (DNA/RNA); $\mathrm{C}=\mathrm{C}$ bending mode of Phe \\
\hline 22 & 1618 & $\mathrm{C}=\mathrm{C}$ Phe, Tyr and Trp \\
\hline 23 & $1550-1700$ & $\mathrm{H}_{2} \mathrm{O}$ bending mode \\
\hline 24 & $1620-1700$ & Amide I \\
\hline
\end{tabular}

the thickness of the pellet exceeded $3 \mathrm{~mm}$.

\section{FTIR measurements}

${ }_{5}$ FTIR measurements were performed using a Perkin Elmer Spotlight 400 microscope system in Transmission Mode. Spectra were collected as an average of 64 scans with a resolution of $2 \mathrm{~cm}^{-1}$. FTIR signals were accumulated over a spectral range of 1000 to $4000 \mathrm{~cm}^{-1}$. An aperture of $10100 \times 100 \mu \mathrm{m}$ was set on groups of $15-20$ cells. Two pellets of each cell lines (two cell culture passages) were investigated.

\section{Data analysis}

Data analysis was performed in Matlab, version R2006 (Mathworks, CA, USA) according to protocols developed in 15 house. Processing of the raw Raman spectra included baseline correction according to an in house automated rubber band model, Extended Multiplicative Signal Correction (EMSC) and 5th order Savitzky-Golay filtering with 13 point window. Processing of the FTIR spectra involved EMSC resonant Mie 20 scattering correction according to the algorithm developed by Bassan et al. ${ }^{48}$. The Matrigel spectrum supplied with the algorithm was used as reference.

After pre-processing the spectra, Principal Component Analysis (PCA) was applied to the data set. PCA is a 25 multivariate statistical technique used for dimensionality reduction and exploratory analysis and has become a very useful tool for spectroscopists allowing for objective interpretation of vibrational spectroscopic data.

\section{Results and Discussion}

\section{Mean spectra analysis}

The mean of 30 Raman spectra recorded from two pellets (approximately 15 spectra per pellet) for $\mathrm{C} 33 \mathrm{~A}$, SiHa, HeLa and CaSki cell lines were derived from the raw spectra via the pre-processing procedures and are presented in figure 1. 35 Assignments of the main peaks (numbered in figure 1) are shown in table 1. In the mean Raman spectra, almost no significant differences between HPV negative C33A and SiHa cells, containing 1-2 HPV copies per cells (low HPV concentration) are discernible. Only the peak at $1583 \mathrm{~cm}^{-1}$ 40 assigned to DNA/RNA and Phenylalanine vibrations was found to vary between $\mathrm{C} 33 \mathrm{~A}$ and $\mathrm{SiHa}$ cells. For cells containing a higher number of integrated HPV copies per cell, HeLa cells (medium HPV concentration) and CaSki cells (high HPV concentration), the observed differences are more ${ }_{45}$ prominent for protein, nucleic acid and lipid vibrations. CaSki cells exhibited a significant increase in Amide I (proteins) intensity at $1660 \mathrm{~cm}^{-1}$ and a decrease in lipid levels at $1093 \mathrm{~cm}^{-}$ $1,1311 \mathrm{~cm}^{-1}$ and $1450 \mathrm{~cm}^{-1}$ compared to C33A, SiHa and HeLa. HPV presence in a cell appears to change protein expression, 50 which may result in the protein variations observed in the Raman spectra, primarily for the Amide I region. Further differences in protein vibrations between the cells affected by non- and low HPV number compared to medium and high HPV number were observed in the Amide III region $\left(1254 \mathrm{~cm}^{-}\right.$ ${ }_{55}{ }^{1}$ ), and protein constituent amino acids Tryptophan (Trp), Proline (Pro), Tyrosine (Tyr) and Phenylalanine (Phe) vibrations at $854 \mathrm{~cm}^{-1}, 935 \mathrm{~cm}^{-1}, 1003 \mathrm{~cm}^{-1}, 1583 \mathrm{~cm}^{-1}$ and $1618 \mathrm{~cm}^{-1}$. Variations in vibrations associated with nucleic 
Table 2 Peak assignments ${ }^{50}$ for FTIR spectra data recorded for cervical cancer cell lines.

\begin{tabular}{|c|c|c|}
\hline Peak reference (figure 2) & Wavenumber $\left(\mathrm{cm}^{-1}\right)$ & FITR peak assignments \\
\hline $\mathrm{I}$ & 1036 & C-C skeletal stretching (proteins) \\
\hline II & 1072 & $\mathrm{PO}_{2}$ symmetric stretching (DNA/RNA) \\
\hline III & 1152 & $\mathrm{C}-\mathrm{C}$ and $\mathrm{C}-\mathrm{O}$ stretching (proteins) \\
\hline IV & $1220-1280$ & $\mathrm{PO}_{2}$ asymmetric stretching (DNA/RNA), Amide III \\
\hline $\mathrm{V}$ & 1312 & $\mathrm{CH}_{2}$ stretching (phospholipids) \\
\hline VI & 1400 & $\mathrm{CH}_{3}$ symmetric stretching (proteins) \\
\hline VII & 1456 & $\mathrm{CH}_{3}$ asymmetric stretching (proteins) \\
\hline VIII & 1546 & Amide II \\
\hline IX & $1620-1700$ & Amide I \\
\hline $\mathrm{X}$ & 1742 & Ester, $\mathrm{C}=\mathrm{O}$ stretching (lipids) \\
\hline $\mathrm{XI}$ & 2854 & $\mathrm{CH}_{2}$ symmetric stretching (lipids) \\
\hline XII & 2926 & $\mathrm{CH}_{2}$ asymmetric stretching (lipids) \\
\hline XIII & 2964 & $\mathrm{CH}_{3}$ asymmetric stretching (lipids and proteins) \\
\hline XIV & 3296 & NH asymmetric stretching (proteins), Amide A \\
\hline
\end{tabular}

acid constituents: $\mathrm{PO}_{2}$ group, A, C, T, $\mathrm{U}$ at $1093 \mathrm{~cm}^{-1}, 720 \mathrm{~cm}^{-}$ $1,782 \mathrm{~cm}^{-1}, 1254 \mathrm{~cm}^{-1}, 1583 \mathrm{~cm}^{-1}$ respectively were also 5 observed. The differences in protein and nucleic acid composition support the molecular data which demonstrates intergration of HPV DNA at chromosome fragile sites and the subsequent downstream effect of HPV E6 and E7 oncoprotein expression on host cell proteins such as $\mathrm{p} 53^{49}$.

10 Approximately 30 infrared signal acquisitions were performed from each investigated sample representing the cell line, giving in total 60 characteristic spectra recoreded from two pellets for every cell line. Mean FTIR spectra for the investigated cell lines derived by the preprocessing procedure 15 are shown in figure 2, with corresponding numbered assignments presented in table 2. Although the Resonant Mie subtraction procedure cannot be considered perfect, as evidenced by the residual background in the region of $\sim 1800 \mathrm{~cm}^{-1}$ to $2800 \mathrm{~cm}^{-1}$ and the small sharp dips at $1735 \mathrm{~cm}^{-1}$ 20 and $2845 \mathrm{~cm}^{-1}$, significantly improved spectra were produced after just one iteration of the algorithm. C33A and SiHa cell lines are again seen to be spectrally very similar, exhibiting just a small difference in the peak at $1072 \mathrm{~cm}^{-1}$ corresponding to nucleic acid vibration (figure 2B). Similar to the Raman 25 results, differences between $\mathrm{C} 33 \mathrm{~A}$, SiHa compared to the HeLa, CaSki cell lines were observed in the FTIR spectra for protein, nucleic acid and lipid levels.

Variations in protein levels are manifest in variations of the peaks at $1036 \mathrm{~cm}^{-1}$ (figure 2B), and the amide bands; Amide 30 III $\left(1242 \mathrm{~cm}^{-1}\right)$, Amide II $\left(1546 \mathrm{~cm}^{-1}\right)$, Amide I $\left(1652 \mathrm{~cm}^{-1}\right)$ and Amide A $\left(3296 \mathrm{~cm}^{-1}\right)$. DNA/RNA variations are primarily expressed through the band at $1242 \mathrm{~cm}^{-1}$, assigned to the $\mathrm{PO}_{2}$ group vibration. Differences in bands corresponding to lipid vibrations at $1740 \mathrm{~cm}^{-1}$ and in the region above $2800 \mathrm{~cm}^{-1}$ are 35 also observed. The peak around $1740 \mathrm{~cm}^{-1}$ is associated with vibrations of lipid esters and is known to indicate active growth of cells ${ }^{51}$. The intensity of the ester peak was found to be the highest for CaSki cell line. This is consistent with the fact that CaSki cells are derived from a metastatic tumour.

\section{${ }_{40}$ Multivariate statistical analysis}

The principal component (PC) scatterplot for Raman spectroscopic results presented in figure $3 \mathrm{~A}$ shows a distinctive separation between the cell lines, suggesting a HPV concentration dependence factor. The C33A (non HPV) ${ }_{45}$ and $\mathrm{SiHa}$ (low HPV concentration, LC) cell lines are grouped together, confirming observed similarities between these two types of cells based on mean spectra analysis. The HeLa (medium HPV concentration, MC) and CaSki (high HPV concentration, HC) cell lines are clearly separated from each 50 other and from the C33A-SiHa group. Although the 3D PCA scatterplot demonstrates the HPV concentration dependent separation, the cell lines are not grouped according to increasing (or decreasing) number of HPV copies. CaSki (HC) cells lie between HeLa (MC) and $\mathrm{SiHa}$ (LC). This suggests ${ }_{55}$ the influence on the data point distribution of another factor HPV strand type. HeLa are cells infected by HPV-18, while CaSki and SiHa are infected by HPV-16. Principal component loadings are presented in figure $3 \mathrm{~B}$. Peak numbers correspond to assignments presented in table 1 . The percent of variance 60 explained by $\mathrm{PC} 1, \mathrm{PC} 2$ and $\mathrm{PC} 3$ is $71.9 \%, 10.8 \%$ and $6.2 \%$, respectively. The first principal component is dominated by the contribution of the $\mathrm{H}-\mathrm{O}-\mathrm{H}$ bending of water, a broad peak in the range of $1550-1700 \mathrm{~cm}^{-1}$ with maximum at $\sim 1644 \mathrm{~cm}^{-1}$ 52 . Water is not, however, the only potential contribution ${ }_{65}$ within this range, as Amide I vibrations ( $\beta$-sheet) exhibited a maximum at $1640 \mathrm{~cm}^{-1}$. Nucleic acid contributions to PC1 may also be present at $782 \mathrm{~cm}^{-1}, 1093 \mathrm{~cm}^{-1}$ and $1583 \mathrm{~cm}^{-1}$ although it is very difficult to judge what is the percentage of contribution of each of these components. The second 70 principal component shows predominantly protein and lipid contributions. Lipids are exhibited at $1095 \mathrm{~cm}^{-1}, 1310 \mathrm{~cm}^{-1}$ and $1450 \mathrm{~cm}^{-1}$, while proteins are at $1660 \mathrm{~cm}^{-1}-$ Amide I ( $\alpha$-helix), $1270 \mathrm{~cm}^{-1}$ - Amide III ( $\alpha$-helix), $1450 \mathrm{~cm}^{-1}, \mathrm{C}=\mathrm{C}$ Phe at $1582 \mathrm{~cm}^{-1}$ and $\operatorname{Trp}$ at $750 \mathrm{~cm}^{-1}$. The third principal component 75 contains a lot of biological information with mainly nucleic acid and protein contributions but only accounts for $6.2 \%$ of variance. There are distinctive peaks corresponding to nucleic acids and protein vibrations. DNA and RNA contributions are observed at $670 \mathrm{~cm}^{-1}, 720 \mathrm{~cm}^{-1}, 782 \mathrm{~cm}^{-1}, 1092 \mathrm{~cm}^{-1}, 1250 \mathrm{~cm}^{-1}$, $801340 \mathrm{~cm}^{-1}$ and $1583 \mathrm{~cm}^{-1}$. PC3 shows a strong influence of variation arising from protein vibrations, Phe $\left(642 \mathrm{~cm}^{-1}\right.$, 

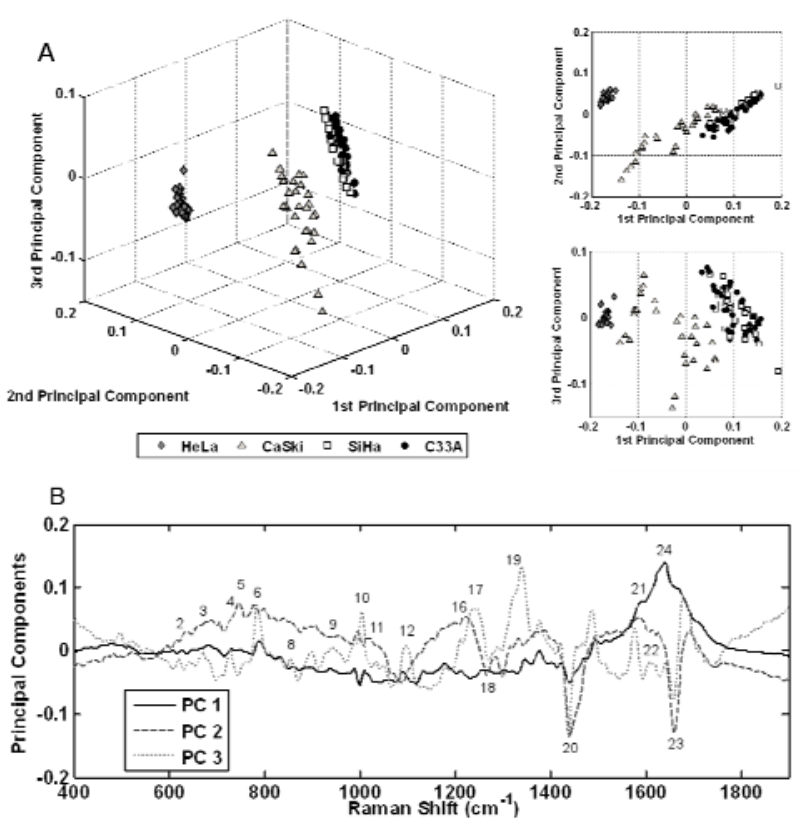

Fig. 3 Principal component analysis for Raman spectroscopy results for cervical cancer cell lines. (A) - Three dimensional PCA scatterplot. Graphs show separation of the cervical cancer cell lines suggesting HPV concentration dependence. (B) - Principal component loadings. Peak assignments correspond to those listed in table 1 .

$1002 \mathrm{~cm}^{-1}, 1031 \mathrm{~cm}^{-1}, 1583 \mathrm{~cm}^{-1}$ and $\left.1618 \mathrm{~cm}^{-1}\right), \operatorname{Trp}\left(1208 \mathrm{~cm}^{-1}\right.$, $1340 \mathrm{~cm}^{-1}$ and $\left.1618 \mathrm{~cm}^{-1}\right)$, Tyr $\left(642 \mathrm{~cm}^{-1}, 854 \mathrm{~cm}^{-1}\right.$ and $1618 \mathrm{~cm}^{-}$ $\left.{ }^{1}\right)$, Pro $\left(854 \mathrm{~cm}^{-1}, 935 \mathrm{~cm}^{-1}\right)$, Val $\left(935 \mathrm{~cm}^{-1}\right)$, Amide I at $101680 \mathrm{~cm}^{-1}$ (disordered) and Amide III at $1260 \mathrm{~cm}^{-1}$ (disordered). The source of variations shown in the loadings is in very good agreement with those observed in the analysis of the mean spectra for the investigated cell lines. The main peaks in the loadings arise from protein, nucleic acid and lipid 15 component vibrations. Each principal component is dominated by different cellular components; water, and possibly nucleic acids and proteins in PC1, lipids and proteins in PC2 and nucleic acids and proteins in PC3. Amide I and Amide III contributions are present in all principal component loadings 20 indicative of differences in structural conformation of the protein $\beta$-sheet in PC1, $\alpha$-helix in PC2 and disordered conformation in PC3. As mentioned previously, variations in protein, nucleic acid and lipid levels arise from the fact that the viral DNA interacts with the cellular DNA, causing 25 reprogramming of protein expression in the cell.

It was noted that the multivariate analysis could be sustantially influenced by water contributions in the region of $1640 \mathrm{~cm}^{-1}$. Repeated over the spectral range $400-1550 \mathrm{~cm}^{-1}$, the PCA gave a similar separation of the cellular types and 30 yielded similar principle components.

Figure 4A shows the three dimensional PCA scatterplot for FTIR spectroscopic results and two dimensional presentation of the plot for the cervical cancer cell lines. It can be clearly seen that the groups of points representing the different types 35 of cells are separated from each other. HPV negative C33A and $\mathrm{SiHa}$ cell line (LC HPV) are grouped very closely in the scatterplot, which is consistent with the PCA of the Raman spectroscopic data for the same cells. Cell lines with greater
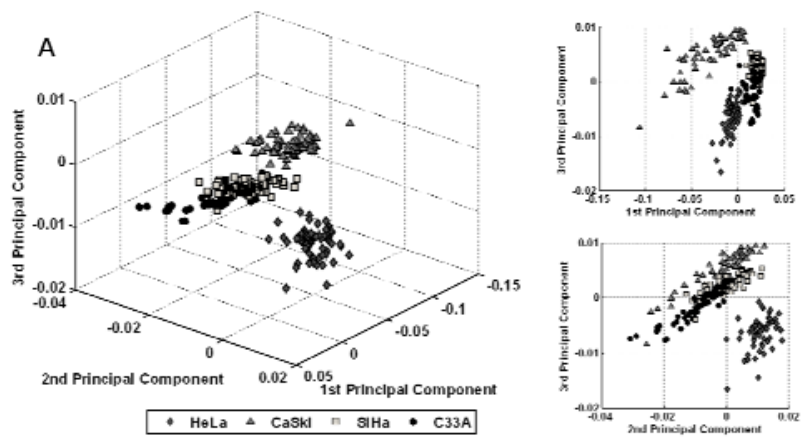

B

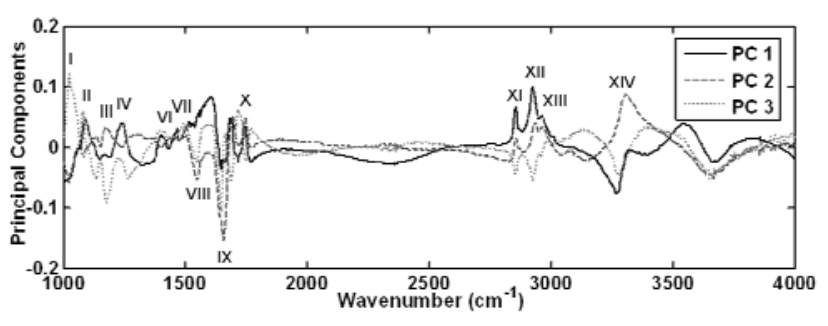

Fig. 4 Principal component analysis for FTIR spectroscopy results for cervical cancer cell lines. (A) - Three dimensional PCA scatterplot showing data points separation according to HPV concentration. (B) Principal component loadings exhibiting variations for the defined nucleic 45 acid, protein and lipid bands.

than $20 \mathrm{HPV}$ copies (HeLa and CaSki) are separated from the C33A and SiHa cells. The data distribution pattern for FTIR spectra is very similar to that seen for Raman spectra, demonstrating a HPV concentration dependence. Principal so component loadings are presented in figure $4 \mathrm{~B}$ and confirm the variations observed for the mean spectra of the cell lines. The percentage variance accounted for by the three first principal components is $81.3 \%, 12.6 \%$ and $3.7 \%$, for $\mathrm{PC} 1$, PC2 and PC3, respectively. All three principal components 55 show variations for the peaks assigned to proteins, primarily the amide bands. Significantly, in the regions of the Amide I and Amide III bands, every PC exhibits a peak corresponding to variations of the different conformational structures of the protein. In $\mathrm{PC} 1$, changes to the contributions of $\beta$-sheet ${ }_{60}$ conformations are expressed in the Amide I $\left(1646 \mathrm{~cm}^{-1}\right)$ and Amide III $\left(1240 \mathrm{~cm}^{-1}\right)$ bands, an observation which lends support to the Raman assignments. In PC 2, changes to $\alpha$ helix contributions are observed in the Amide I region $\left(1660 \mathrm{~cm}^{-1}\right)$ and in $\mathrm{PC} 3$, changes to disordered structure ${ }_{65}$ vibrations in Amide I $\left(1686 \mathrm{~cm}^{-1}\right)$ and Amide III $\left(1260 \mathrm{~cm}^{-1}\right)$. Changes to the Amide II bands are apparent in PC2 and PC3 at $1548 \mathrm{~cm}^{-1}$ and $1546 \mathrm{~cm}^{-1}$, respectively.

With respect to $\mathrm{PC} 3$, there is a separation of the CaSki group from the other cell lines and it is important to note that in the ${ }_{70} \mathrm{PC} 3$ loading there is a distinctive protein peak at $1036 \mathrm{~cm}^{-1}$, which has a clearly different contribution in the CaSki mean spectrum compared to other cell lines (figure 2B).

Bands corresponding to changes in nucleic acid vibrations are also exhibited in all principal component loadings $\left(1072 \mathrm{~cm}^{-1}\right.$, $751242 \mathrm{~cm}^{-1}$ ) again suggesting the interaction of cellular and viral DNA. PC's show also a lipid contribution manifest very clearly in the range of $2850 \mathrm{~cm}^{-1}-2970 \mathrm{~cm}^{-1}$. Similar to the Raman spectroscopic results, the lowest intensity of lipid 
peaks were observed for the CaSki cell line. Lipid variations may be due to interaction of high risk HPV with the plasma membrane, which has a direct influence on lipid rafts ${ }^{53}$.

\section{Conclusions}

${ }_{5}$ Vibrational spectroscopic techniques have been applied to the analysis of cervical cancer cell lines (C33A, SiHa, HeLa and CaSki) delivering complementary information about the biochemical composition of the investigated samples. Mean Raman and FTIR spectra of C33A and SiHa cells are very 10 similar indicating that cells not infected by HPV and those affected by a very low number of HPV copies are biochemically very similar. Very subtle differences for these cell lines were observed for the peaks assigned to nucleic acid vibrations and they are well differentiated by PCA of the two 15 data sets alone (data not shown). This fact suggests that although the cell lines are very similar, there is a change in the cellular DNA/RNA, possibly due to the fact of integration of cellular DNA with 1-2 copies of HPV DNA for SiHa cells. PCA confirms the observations about the similarities between

20 these two cell lines, grouping $\mathrm{C} 33 \mathrm{~A}$ and $\mathrm{SiHa}$ cells close to each other in the PCA scatterplot.

Mean Raman and FTIR spectra of the cells containing a higher number of HPV copies, HeLa and CaSki significantly differ from the signals recorded from $\mathrm{C} 33 \mathrm{~A}$ and $\mathrm{SiHa}$. ${ }_{25}$ Variations observed in protein, nucleic acid and lipid levels were also confirmed by PCA analysis. Variations of Raman peaks assigned to Trp, Pro, Tyr and Phe are remarkable, and are in good agreement with the observation made by Jess et al of differences between HPV positive (PHK E7) and HPV

30 negative cell lines (PHK) based on peaks assigned to Phe, Pro and $\mathrm{Tyr}^{44}$.

Raman and FTIR PCs are dominated by features associated with changes of protein conformation structures; $\beta$-sheet, $\alpha$ helix and disordered structure in $\mathrm{PC} 1, \mathrm{PC} 2$ and $\mathrm{PC} 3$, 35 respectively. A decrease in lipid levels were observed in the Raman and FTIR signals for the CaSki cell line. The observed changes in proteins are evidence that HPV influences protein balance within the cell resulting in under- and over expression of certain proteins, while, lipid peak variations are possibly 40 due to disruption of the membrane functionality by the virus. PCA applied to Raman and FTIR results has successfully discriminated all cervical cancer cell lines indicating HPV concentration dependence between cells with no and low number (0-2) of HPV copies per cell (C33A, SiHa), medium 45 number $(10-50)$ of HPV copies per cell (HeLa) and high number (60-600) of HPV copies per cell (CaSki). In summary, our results show that vibrational spectroscopy and PCA can discriminate between the cells affected by the various number of HPV copies and confirm the FTIR study of Kelly at al. on ${ }_{50}$ cervical cells ${ }^{45}$. The biochemical origins of the discrimination can also be elucidated. The knowledge about differences in Raman and FTIR spectra between the HPV negative cells and these affected by various numbers of HPV copies is very important and has potential application in systems for cervical 55 cancer screening based on vibrational spectroscopic techniques. This new technology for cervical screening not only can distinguish cervical cells based on biochemical content but also can elucidate the effect of HPV on the cells. It is noted, however, that the sample preparation protocol for ${ }_{60}$ each technique is different and in both cases less than ideal, and that a pellet preparation protocol which preserves the biochemical integrity of the cells is desirable.

\section{Acknowledgement}

This work was funded by the Department of Education and ${ }_{65}$ Science Technological Sector Research Strand III programme and enabled through the National Biophotonics and Imaging Platform, Ireland, and the Integrated NanoScience Platform for Ireland, both funded by the Irish Government's Programme for Research in Third Level Institutions, Cycle 4, National 70 Development Plan 2007-2013.

\section{Notes and references}

${ }^{a}$ RESC, Focas Research Institute, Dublin Institute of Technology, Kevin Street, Dublin 8, Ireland. E-mail: kamila.m.ostrowska@gmail.com.

${ }^{b}$ School of Biological Sciences, Dublin Institute of Technology, Kevin 75 Street, Dublin 8, Ireland.

${ }^{c}$ Focas Research Institute, Dublin Institute of Technology, Kevin Street, Dublin 8, Ireland.

${ }^{d}$ Department of Pathology, Coombe Women \& Infants University

Hospital, Dolphin’s Barn Street, Dublin 8, Ireland. 80

1. S. Bedford, Br J Nurs, 2009, 18, 80-84.

2. H. M. Shingleton, R. L. Patrick, W. W. Johnston and R. A. Smith, Ca-a Cancer Journal for Clinicians, 1995, 45, 305-320.

85 3. K. Nanda, D. C. McCrory, E. R. Myers, L. A. Bastian, V. Hasselblad, J. D. Hickey and D. B. Matchar, Ann Intern Med, 2000, 132, 810-819.

4. K. S. Cuschieri, H. A. Cubie, M. W. Whitley, G. Gilkison, M. J. Arends, C. Graham and E. McGoogan, Journal of Clinical Pathology, 2005, 58, 946-950.

5. W. A. Tjalma, T. R. Van Waes, L. E. Van den Eeden and J. J. Bogers, Best Pract Res Clin Obstet Gynaecol, 2005, 19, 469483.

6. J. M. Walboomers, M. V. Jacobs, M. M. Manos, F. X. Bosch, J. A. $95 \quad$ Kummer, K. V. Shah, P. J. Snijders, J. Peto, C. J. Meijer and N. Munoz, J Pathol, 1999, 189, 12-19.

7. M. H. Mayrand, E. Duarte-Franco, I. Rodrigues, S. D. Walter, J. Hanley, A. Ferenczy, S. Ratnam, F. Coutlee and E. L. Franco, N Engl J Med, 2007, 357, 1579-1588.

1008 . S. K. Chang, I. Pavlova, N. M. Marin, M. Follen and R. RichardsKortum, Gynecol Oncol, 2005, 99, S61-63.

9. L. Von Bertalanffy, M. Masin and F. Masin, Cancer, 1958, 11, 873 887.

10. S. K. Chang, Y. N. Mirabal, E. N. Atkinson, D. Cox, A. Malpica, M. $105 \quad$ Follen and R. Richards-Kortum, J Biomed Opt, 2005, 10, 024031.

11. S. M. Chidananda, K. Satyamoorthy, L. Rai, A. P. Manjunath and V. B. Kartha, Int J Cancer, 2006, 119, 139-145.

12. C. Redden Weber, R. A. Schwarz, E. N. Atkinson, D. D. Cox, C. 110 Macaulay, M. Follen and R. Richards-Kortum, J Biomed Opt, 2008, 13, 064016. 
13. Sujatha, L. Rai, P. Kumar, K. K. Mahato, V. B. Kartha and C. Santhosh, J Biomed Opt, 2008, 13, 054062.

14. R. K. Dukor, in Handbook of Vibrational Spectroscopy, eds. J. M. Chalmers and P. R. Griffiths, John Wiley \& Sons Ltd, New York, 2002, vol. 5.

15. H. H. Mantsch, L. P. Choo-Smith and R. A. Shaw, Vibrational Spectroscopy, 2002, 30, 31-41.

16. E. B. Hanlon, R. Manoharan, T. W. Koo, K. E. Shafer, J. T. Motz, M. Fitzmaurice, J. R. Kramer, I. Itzkan, R. R. Dasari and M. S. Feld, Phys Med Biol, 2000, 45, R1-59.

17. R. K. Sahu and S. Mordechai, Future Oncol, 2005, 1, 635-647.

18. P. Lasch, L. Chiriboga, H. Yee and M. Diem, Technol Cancer Res Treat, 2002, 1, 1-7.

19. R. Manoharan, Y. Wang and M. S. Feld, Spectroc. Acta Pt. A-Molec. 15 Biomolec. Spectr., 1996, 52, 215-249.

20. C. Krafft, Analytical and Bioanalytical Chemistry, 2004, 378, 60-62.

21. F. M. Lyng, E. Ó Faoláin, J. Conroy, A. D. Meade, P. Knief, B. Duffy, M. B. Hunter, J. M. Byrne, P. Kelehan and H. J. Byme, Experimental and Molecular Pathology, 2007, 82, 121-129.

20 22. P. T. T. Wong, R. K. Wong, T. A. Caputo, T. A. Godwin and B. Rigas, Proceedings of the National Academy of Sciences of the United States of America, 1991, 88, 10988-10992.

23. B. J. Morris, C. Lee, B. N. Nightingale, E. Molodysky, L. J. Morris, R. Appio, S. Sternhell, M. Cardona, D. Mackerras and L. M.

25 Irwig, Gynecologic Oncology, 1995, 56, 245-249.

24. P. T. T. Wong, S. Lacelle, M. F. K. Fung, M. Senterman and N. Z. Mikhael, Biospectroscopy, 1995, 1, 357-364.

25. H. M. Yazdi, M. A. Bertrand and P. T. T. Wong, Acta Cytologica, 1996, 40, 664-668.

30 26. M. F. K. Fung, M. Senterman, P. Eid, W. Faught, N. Z. Mikhael and P. T. T. Wong, Gynecologic Oncology, 1997, 66, 10-15.

27. M. A. Cohenford and B. Rigas, Proceedings of the National Academy of Sciences of the United States of America, 1998, 95, 1532715332.

35 28. A. Mahadevan-Jansen, M. F. Mitchell, N. Ramanujam, A. Malpica, S. Thomsen, U. Utzinger and R. Richards-Kortum, Photochemistry and Photobiology, 1998, 68, 123-132.

29. U. Utzinger, D. L. Heintzelman, A. Mahadevan-Jansen, A. Malpica, M. Follen and R. Richards-Kortum, Applied Spectroscopy,

40 2001, 55, 955-959.

30. S. Neviliappan, L. F. Kan, T. T. L. Walter, S. Arulkumaran and P. T. T. Wong, Gynecologic Oncology, 2002, 85, 170-174.

31. M. Diem, L. Chiriboga, P. Lasch and A. Pacifico, Biopolymers, 2002, 67, 349-353.

45 32. M. J. Romeo, M. A. Quinn, F. R. Burden and D. McNaughton, Biopolymers, 2002, 67, 362-366.

33. S. Mordechai, R. K. Sahu, Z. Hammody, S. Mark, K. Kantarovich, H. Guterman, A. Podshyvalov, J. Goldstein and S. Argov, J Microsc, 2004, 215, 86-91.

50 34. B. R. Wood, L. Chiriboga, H. Yee, M. A. Quinn, D. McNaughton and M. Diem, Gynecol Oncol, 2004, 93, 59-68.

35. C. M. Krishna, G. D. Sockalingum, B. M. Vadhiraja, K. Maheedhar, A. C. Rao, L. Rao, L. Venteo, M. Pluot, D. J. Fernandes, M. S.
Vidyasagar, V. B. Kartha and M. Manfait, Biopolymers, 2007, $55 \quad \mathbf{8 5}, 214-221$.

36. R. Sindhuphak, S. Issaravanich, V. Udomprasertgul, P. Srisookho, S. Warakamin, S. Sindhuphak, R. Boonbundarlchai and N. Dusitsin, Gynecol Oncol, 2003, 90, 10-14.

37. B. Rigas, K. LaGuardia, L. Qiao, P. S. Bhandare, T. Caputo and M. 60 A. Cohenford, J Lab Clin Med, 2000, 135, 26-31.

38. A. Robichaux-Viehoever, E. Kanter, H. Shappell, D. Billheimer, H. Jones and A. Mahadevan-Jansen, Applied Spectroscopy, 2007, 61, 986-993.

39. F. H. Shirazi, N. Vakili, K. Abdi, A. Farhadi and F. B. Rahimi, Iranian Journal of Pharmaceutical Research, 2007, 6, 107113.

40. M. J. Walsh, M. J. German, M. Singh, H. M. Pollock, A. Hammiche, M. Kyrgiou, H. F. Stringfellow, E. Paraskevaidis, P. L. Martin-Hirsch and F. L. Martin, Cancer Letters, 2007, 246, 111.

41. M. J. Walsh, M. N. Singh, H. M. Pollock, L. J. Cooper, M. J. German, H. F. Stringfellow, N. J. Fullwood, E. Paraskevaidis, P. L. Martin-Hirsch and F. L. Martin, Biochemical and Biophysical Research Communications, 2007, 352, 213-219.

75 42. M. J. Walsh, M. N. Singh, H. F. Stringfellow, H. M. Pollock, A. Hammiche, O. Grude, N. J. Fullwood, M. A. Pitt, P. L. Martin-Hirsch and F. L. Martin, Biomark Insights, 2008, 3, 179-189.

43. J. G. Kelly, M. N. Singh, H. F. Stringfellow, M. J. Walsh, J. M. 80 Nicholson, F. Bahrami, K. M. Ashton, M. A. Pitt, P. L. Martin-Hirsch and F. L. Martin, Cancer Lett, 2009, 274, 208217.

44. P. R. Jess, D. D. Smith, M. Mazilu, K. Dholakia, A. C. Riches and C. S. Herrington, Int J Cancer, 2007, 121, 2723-2728.

85 45. J. G. Kelly, K. T. Cheung, C. Martin, J. J. O'Leary, W. Prendiville, P. L. Martin-Hirsch and F. L. Martin, Clin Chim Acta, 2010, 411, 1027-1033.

46. A. D. Meade, C. Clarke, F. Draux, G. D. Sockalingum, M. Manfait, F. M. Lyng and H. J. Byrne, Anal Bioanal Chem, 2010.

90 47. Z. Movasaghi, S. Rehman and I. U. Rehman, Appl. Spectrosc. Rev., 2007, 42, 493-541.

48. P. Bassan, A. Kohler, H. Martens, J. Lee, H. J. Byrne, P. Dumas, E. Gazi, M. Brown, N. Clarke and P. Gardner, Analyst, 2010, 135, 268-277.

95 49. N. Murphy, M. Ring, C. C. Heffron, B. King, A. G. Killalea, C. Hughes, C. M. Martin, E. McGuinness, O. Sheils and J. J. O'Leary, J Clin Pathol, 2005, 58, 525-534.

50. Z. Movasaghi, S. Rehman and I. U. Rehman, Appl. Spectrosc. Rev., 2008, 43, 134-179.

100 51. H. Y. Holman, M. C. Martin, E. A. Blakely, K. Bjornstad and W. R. McKinney, Biopolymers, 2000, 57, 329-335.

52. J. J. Max and C. Chapados, J Chem Phys, 2009, 131, 184505.

53. F. A. Suprynowicz, G. L. Disbrow, E. Krawczyk, V. Simic, K. Lantzky and R. Schlegel, Oncogene, 2008, 27, 1071-1078. 